\title{
The Problem of Capitalism in the Scholarship on Contemporary Spirituality
}

\begin{abstract}
Capitalism has been a rare theme in the scholarship on spirituality. However, some very interesting attempts to think spirituality in relation to capitalism have been made. The focus in this article will be on four examples: Kimberly Lau, Jeremy Carrette and Richard King, Slavoj Žižek and Gordon Lynch. This list of scholars is not exhaustive, but I have chosen these on the basis that their works have contributed to recent discussion and that I have found them stimulating. All the chosen scholars are critical of contemporary capitalism. Lynch understands spirituality to be progressive and an anti-capitalist ideology, while all the others deem contemporary spirituality to be somehow capitalist in contributing to its ideology, practice and consumerist ethos. By describing and analysing these positions, it will be argued that although the scholarly works have been strong in either describing the spiritual practices or theorising capitalism, these two dimensions have been fairly distinct. Therefore, there is still space for scholarship which could connect detailed empirical descriptions with theories of capitalism.
\end{abstract}

\section{Consumerist spirituality}

Kimberly Lau has analysed books and practices related to aromatherapy, macrobiotic eating, yoga and tai chi in the United States. In her book, New Age Capitalism: Making Money East of Eden (2000), she argues that although these practices portray themselves as critical towards capitalism, they are perfect products of consumer culture. They present themselves as tools for personal transformation through a non-western paradigm of health and wellness. All this is introduced as an anti-materialist project, but it is fully commodified: macrobiotic eating is expensive, Yoga Zone costs \$10oo USD annually (p. 17) and the aromatherapeutic antidote for the inner emptiness that cannot be filled with external prosperity requires external prosperity to be acquired (p. 34). 
The problem with spirituality is its unrealistic nostalgia for an ancient and non-western world and the romanticisation of nature and naturalness. Lau argues that this is precisely the operation which makes it an attractive option as a consumer item.

Another problem is that spiritualities adjust the American self-reliance and individualism in themselves, thus not only recontextualising some Eastern traditions into a 'pick'n'mix' style, but also carving off space from addressing public and social issues and maintaining the common good. In this discourse social crises appear to be individual crises, or, to put it in other words, it encourages us to seek biographical solutions to systemic problems. It is primarily the responsibility of the individual, not that of society, to pursue happiness, and using the products of spirituality is offered as a way (or even the way) to achieve the ultimate goal of happiness.

The reader is tempted to ask, is there something wrong with spending money on spiritual practices and products, and if so, where should we put our money? It is noticeable that in the acknowledgements, the author thanks her mountain-biking friends and builds a hierarchical opposition between New Age discourse and mountain-biking. At this point, it would be possible to analyse the ways in which mountain-biking itself is commodified. There are magazines to buy and read, different products from designer gloves to helmets to choose from, and various trails to travel to. Therefore, mountainbiking cannot provide the context for resistance. In addition, if the author's preferred choice is itself thoroughly commodified, the consumerism itself cannot be the main aim of the critique.

Lau does not tell us what she thinks would be the best way to resist capitalism, or whether that is even the point. She just seems to be annoyed because in contemporary spirituality there is a gap between the product and its promises and a discrepancy between the product and the stated ideology. She argues, contrary to the advertisement of spirituality, that purchase is not a political act (p. 14), especially because it bypasses the issues of class and equality. The real problem is the belief that consumption is political action. However, if that is the case, then the critique of consumerism is secondary to the problem of believing something which is not true and which might have unwanted social consequences. At least mountain-biking is sincere, because it is not advertised as an alternative to consumer capitalism.

The author does not present an explicit theory of capitalism. Capitalism is a more general catchword in writing about consumerism and consumer culture. Therefore, the outcome is simply a critique of consumerist spirituality and the problem of capitalism itself remains in the background. This is 
the major problem, despite the rich description of some of the contemporary spiritualities. What makes Lau's account important, in addition to being an empirical description, is its identification and analysis of individualising tendencies in both spiritual practices and society in general.

\section{Individualising spirituality}

Individualising tendencies in contemporary spirituality have been analysed more thoroughly in Jeremy Carrette and Richard King's Selling Spirituality: The Silent Takeover of Religion (2005). It is an example of a critical pamphlet on the discourse on spirituality. The authors mainly use books as their primary data. The focus is not exclusively on the bookshops with their 'mind, body and spirit' shelves, but also on corporations and on the public sector (for example healthcare and education), which have become important locations for the discourse of spirituality.

The authors argue that what we used to know as 'religion' has become commodified and re-branded as 'spirituality' in the 1990s. What might be an even more important issue than commodification is that in spirituality old traditions are privatised or individualised by leaving questions of community and social justice off the agenda. This is exemplified in the analysis of Deepak Chopra's bestsellers. The authors quote the list of Chopra's ten key steps to happiness from Ageless Body, Timeless Mind (1993) and show that there is some superficial resemblance to the Buddhist tradition, but what is more important from a critical point of view is that none of the steps point toward collective action and stopping social injustice. Instead, the steps are fully located in the private self (Carrette \& King 2005: 100). This is an example of contemporary life which individualises both risk and success. According to the authors, this re-branding and individualising is concomitant with-and even instrumental to-neoliberal capitalism's emphasis on private individuals and the decline of the collective dimension.

There are some problematic assumptions which help Carrette and King to develop their critique. At some points they seem to construct an opposition between tradition and spirituality and also between religion and spirituality. Although at other points they resist these oppositions, they seem to immerse into those as if a tradition is worth saving and 'quoting' only as a whole. Furthermore, 'religion' is valued somehow more than 'spirituality'. I find this problematic even though their most interesting message in relation to tradition is the fact that in spirituality the issue of social justice is almost absent. 
In spirituality everything is tailored according to the needs of the individual, not the community. Previously the authors have been criticised for assuming the existence of some kind of authentic religion or spirituality outside or behind commodified versions (McCutcheon 2003: 8-9, 233-40). ${ }^{1}$ Despite this impression, which is easy to get, their work, however, should not be read as an argument for the heavenly nature of strong traditional communities.

The authors emphasise that there is no truly authentic thing behind different versions of religiosity or spirituality and that their project is 'not motivated... in order to appeal to some privileged space of ancient religious authenticity, some nodal point where "true religion" or "true spirituality" might be found' (p. 171). However, at the same time they seem to pose traditional communities as a counter-force to spirituality-'the richest intellectual examples we have of humanity's collective effort to make sense of life, community and ethics' (Carrette \& King 2005: 182). The authors might mean that there is no authentic religion or spirituality, because everything is already immersed in power relations. However, they contend that traditional religious communities are the best antidotes to neoliberal and individual spirituality. This is how it is possible to make sense of the two different arguments as: (1) individualist, consumerist, corporatist and capitalist 'spirituality. . . is a hidden form of social manipulation of the same order as oppressive forms of thought-control associated with religious traditions in previous eras' (p. 84) and (2) 'it is the religious traditions themselves that are in the best position to provide alternative conceptions of "spirituality" and resist neoliberal takeover' (p. 139). According to these arguments, 'religion' is the historical poison and contemporary medicine. The problem is, however, that the authors partly neglect the fact that traditional religious communities are sometimes in contemporary societies still hierarchical, sexist, racist, homophobic and pro-capitalist constructs and are therefore also present rich examples of collective oppression and control.

It is easy to present some further questions to the authors. What is wrong with buying things? Is it worse to spend your money on Deepak Chopra's books than Carrette and King's? Is there any difference between the two? Is there even a target of the critique? Should the proper target be the Prosperity Gospel instead? If these kinds of question are valid, the authors are not offering a plausible justification for their critique. However, I think that these (2000) and Richard King's Orientalism and Religion (1999), not Selling Spirituality which was published later. 
questions, while easy to pose, are partly misleading. Despite the catchy title of the book, it is successful in obscuring its most vital point, which is not the lament that people buy books or spirituality products, or that religion has been taken over, but that the discourse on spirituality is enhancing the kind of individuality which is favourable to the triumph of neoliberal capitalism. The ideological critique is more important than the critique of consumerism and commodification as such, although both aspects are present in the study.

\section{The spirituality of global capitalism}

The Slovenian psychoanalytic and philosopher Slavoj Žižek has dealt briefly with spirituality, Western Buddhism and New Age in many of his books and articles (see for example Žižek 1999, 2000, 2001, 2003). He does not analyse any systematically collected material when he writes about spirituality and New Age. Instead, he refers to the popularity of Western Buddhism, Taoism and New Age discourse. ${ }^{2}$ His interest in spirituality derives from the willingness to think deeply upon global capitalism and its ideology.

The emergence of contemporary spirituality and its relation to capitalism is narrated in terms of post-industrial or post-Fordist society: if in Weber's analysis of early modernity in Protestant Ethic and the Spirit of Capitalism the Protestant work ethic was seen as stimulating the emergence of Western capitalism, the contemporary situation, according to Žižek, should be analysed under the title of The Taoist Ethic and the Spirit of Global Capitalism (Žižek 2001: 13).

Žižek sees the emergence and popularity of New Age, Taoism, Western Buddhism and different kinds of spiritualities as ideological supplements of global capitalism. He perceives Christianity, and especially St Paul's theology, in a more positive manner, as an ally of Marxist politics. He also deems Buddhism to have a similar radical potential in The Fragile Absolute (2000),

2 In addition, he deals briefly with James Redfield's bestseller Celestine Prophecy (in Žižek 1999: 384-5). The analysis on Redfield's bestseller is somewhat different from the analysis of Taoism and Western Buddhism, albeit no less critical. The main idea in Redfield's book is that encounters carry a secret message by which we come to know our inner self. According to Žižek, we lose the Other itself and reduce it to a means in our journey of self-realization (2004: 127-8). This structure is similar to a self-sufficient consumerist self who finds from the Other only messages concerning himself. Therefore he writes that 'New Agers are not giving us even an ideal spiritual supplement to commercialized everyday life; they are giving us the spiritualized/ mystified version of this commercialized everyday life itself. ... (1999: 385). 
but he changes his view in the following books, On Belief (2001) and The Puppet and the Dwarf (2003) in particular (see Kotsko 2008: 71-2). The attitude towards spirituality and Western Buddhism has been consistently negative. According to Žižek, spiritualities function as a supplement, which means they offer a territory for relaxation and for gaining distance from the frantic pace of capitalism. Žižek (2001: 12) writes that 'although "Western Buddhism" presents itself as the remedy against the stressful tension of the capitalist dynamics, allowing us to uncouple and retain inner peace and Gelassenheit, it actually functions as its perfect ideological supplement.' Spiritualities offer a way out of the frantic pace of contemporary life with which we are unable to cope psychologically and work as sustaining the belief that 'you are not really playing the game. This view is based on the idea of fetish: in the same manner as fetishist attachment embodies a lie which helps one to carry on, spirituality enables people to sustain the unbearable truth and to cope with, and ultimately accept, the real and crude world of global capitalism.

According to this view, fetishists, or practitioners of spiritualities in this context, are not 'dreamers lost in their private worlds' (Žižek 2001: 13), as especially Lau seems to think of people who consider spirituality as resistance to consumer capitalism. They are fully participating in the hegemony of global capitalism. This is the 'social involvement' of spirituality. Elsewhere Žižek (2008: 18) suggests even that there is a connection between 'spirituality' (as distinct from 'old-fashioned religion') and what he mockingly calls 'liberal communism' which supports contemporary capitalism despite its ostensibly anti-capitalist disposition.

There are differences and similarities to be observed in Žižek's work in comparison to other critiques of spirituality. The basic difference is that his is not a critique of buying goods. There is no moral advice given that you should spend your money better on the items or services that are delivering what they promise. The similarity is that the analysis implies what Lau, Carrette and King stress: that the spirituality discourse facilitates the understanding according to which collective social and political problems are seen as if they were individual and subjective matters (Bowman 2007: 32).

There are two basic problems in Žižek's account of spirituality as a fetishist supplement of global capitalism. First, he does not offer any detailed or systematic empirical examples of analysis. When Simon Critchley (2003: 66) claims that Žižek's critique of multiculturalist and leftist politics is not approached according to political categories based on people's everyday lives, I propose that it is possible to apply the notion to this case: the critique of spirituality is not based on a detailed account of people's practices, but on very 
general and casual evidence. Second, his theoretical position in which everything comes down to economics after scratching the surface is too simple. These two issues are interconnected in the sense that the first is a consequence of the latter, because the theoretical position provides all the answers. As a result, the analysis tells us more about the fetishist mode of ideology-in contrast to the symptomal mode of ideology where repressed trauma returns in the symptom-in contemporary capitalism. The fetishist mode of ideology may intersect with spiritualities, but it is not the same thing as to say that they fully overlap.

Žižek has a persuasive interest in debating the role, function and form of global capitalism, but he is not convincing in his knowledge of the empirical details of spirituality. Furthermore, Žižek's overall position as a commentator of the global system of capitalism gives him the excuse to abstain from a detailed analysis of particularities (Bowman 2007: 40). This critique of Žižek's position is based on the idea that the economic system is contingently and politically instituted and modified. This implies also that the discursive practices related to spirituality cannot be completely outside of the economic system. Therefore, the question of the relation and interconnectedness of global capitalism and spirituality is highly relevant for any study of discursive practices labelled 'spiritual.' To put it briefly, even if scholars of spirituality can easily point out the weakness of Žižek's knowledge on the subject, there are still lessons to be learnt, as he is asking the right question. Žižek's contribution lies in him explicitly posing the problem of the relation between spirituality and capitalism.

\section{Progressive spirituality?}

All of the three examples I have dealt with above agree that spirituality supports capitalism. Only Carrette and King emphasise that there are other kinds of spirituality in addition to the capitalist one. The other side of capitalist spirituality has been mapped by Gordon Lynch in his book entitled The New Spirituality: An Introduction to Progressive Belief in the Twenty-First Century (2007).

What Lynch describes is a loosely associated meaning-system which shares the idea of an immanent divinity. It is located mostly, but not solely, outside or beyond institutionally organized and established practices which are labelled as religions. According to Lynch, it can also be found across institutions and established traditions, but the examples he chooses are mostly situated out- 
side of these. This contemporary 'spirituality' does not form a theologically coherent belief-system, but it has shared values and recurrent patterns-the unity of ineffable and immanent divine, pantheism/panentheism, mysticism and the divine feminine, the sacralization of nature and the sacralization of the self (Ch. 2)-found in books, websites and meetings. Because the values of the spirituality described are somewhat green, left-wing, pro-science and often include a critical attitude towards capitalism, Lynch decides to call it progressive. It is thus analytically separated from the wider field of spirituality which includes a range of liberal and conservative attitudes. The phenomenon certainly exists, and its description and an examination of its roots is convincing. The main issues concerning this are the questions as to what it should be called and what its relation to capitalism is.

One problem with the term 'progressive' is that the author does not clarify whether it is an emic or etic concept. It seems to me that it is partly an insider concept, but Lynch widens it somewhat uncritically and without further reflection to his own vocabulary. First of all, does the fact that something is in accordance with modern knowledge and cultural norms mean that it is progressive? If it is connected to 'green and left-of-centre political concerns' (p. 19) as Lynch puts it, it might do so. However, if it typically 'defines itself over and against forms of religion that are both theologically and politically conservative' (p. 20) as Lynch suggests, then it is not necessarily different from liberal spirituality or religiosity ${ }^{3}-$ not even when its limits of toleration are 'assumptions about the divine, nature and the self' (p. 61).

My point is this: the author cannot substantiate the progressive side of the phenomenon described. This becomes evident in noticing that the examples are seldom anti-capitalist and practically never linked to anti-capitalist social

It would be important to analyse the motivations in choosing the word 'spirituality' instead of 'religiosity'. Why is the term 'spirituality' now flourishing and being taken as more attractive than 'religiosity'? Some decades ago things were different. For example, the North-American pragmatist philosopher John Dewey made a distinction between 'a religion' and 'religious' in his A Common Faith, originally published in 1934. He suggested that 'a religion' refers to a belief system and body of practices which have some kind of relation to institution or organisation, whereas 'religious' referred to experiences that bring adjustment in life. The 'religious' was about 'morality touched by emotion', about having moral faith in ideal ends. It was about seeing humanity as a part of a larger whole in this world (Dewey 1960: 1-28). The majority of people would not characterize that as 'religious' today, but rather as 'spiritual' or perhaps as the 'sacralisation of life'. In the case of Lynch, the term 'spirituality' is used in emphasising the distance between conservative institutions (religion) and progressive individuals and networks (spiritual), but a comprehensive study would go beyond individual scholars to analysing the emergence of the discourse on spirituality. 
movements and networks. Therefore, the anti-capitalist or progressive nature of the phenomenon itself remains vaguely articulated. Lynch writes that progressive spirituality is 'often at the forefront of critiquing the economic injustice and environmental harm caused by capitalism' (p. 66). If it is there at all, it definitely is not at the forefront with other explicitly anti-capitalist social movements. ${ }^{4}$ It is possible that I am not informed well enough, but the author does not offer evidence either. Most of the examples of social and political activism are taken from the United States and deal with the attempts to change religious organisations, to gain public recognition for holistic spirituality and to support the victims of hurricane Katrina (pp. 79-82). There is nothing specifically progressive or anti-capitalist in that. This is partly understood by the author himself:

Given that much of the literature on progressive spirituality has been concerned so much with defining its theological/thealogical position, it is perhaps not surprising that writers on progressive spirituality have not always gone on to offer so much by way of detailed social and economic analysis (Lynch 2007: 158).

This is true but there are no good reasons to assume that theological problems will be solved and social and economic issues will therefore appear more explicitly on the agenda. Therefore, the progressiveness itself is a kind of future wish or virtual potential, not an evident part of the actual phenomenon. Furthermore, if the anti-capitalist attitude remains at the individual level and is not connected to practices of other movements, it easily turns into a commodity, as is the case with what Kimberly Lau calls New Age capitalism.

To put it simply, the new spirituality described by Lynch seems to lack a theory of capitalism and a theory of resistance. Therefore, it is not easy to

As Paul Heelas emphasised in his response to the early version of this article, a major proportion of 'spiritual' people are middle-aged women whose attitudes and values are mildly, not radically, counter-cultural. One example even suggests that the old-fashioned religious institutions might be more active than spiritual seekers in anti-capitalist and anti-globalist demonstrations, even though the statistics are not reliable or comparable between religious institutions and spiritual groups. The Economist magazine reported on the World Forum meeting in Nairobi in January 2007, where the biggest single group of anti-poverty campaigners were Roman Catholics, who gathered approximately 20,000 people for a protest march (see 'Kingdoms of this world, and otherwise' in The Economist, 25 January 2007, http://www.economist.com/world/international/displaystory.cfm?story_id=E1_ RGDNJQQ). 
agree with its progressive nature. Although it is another issue to deal with the concept of spirituality, I would call the phenomenon a liberal religiosity which is located mainly outside institutionalised, organised and established traditions. Lynch himself is openly pro-spirituality and critical towards contemporary capitalism, but in the analysis of the phenomenon there are not many signs of serious anti-capitalism.

\section{Theorising contemporary spirituality in the societies of control}

Although my aim is not to provide a fully developed alternative framework for the already existing and previously used approaches, it is useful to try to avoid the two extreme alternatives that are reminiscent of the study of fandom-one which sees every kind of politically correct dimension in the discourse on spirituality as progressive or anti-capitalist and the other which deems every kind of reference to spirituality or Eastern wisdom as a surrender to consumer culture or neoliberal ideology. ${ }^{5}$ What seems to be a more urgent task is to analyse the interaction of capitalism and spirituality and to see how the changes in social formations of power provide a space for the discourse on spirituality to emerge and flourish.

It is suggested that the main traits in postmodern spirituality are an emphasis on the individual, a rejection of the idea of a pure tradition, and an incredulity towards the authority of established institutions. As Jeremy Carrette (2004: 364) writes in his article 'Postmodern Spirituality': 'The sacred space is no longer delimited simply by institutional power, but is rather contested and relocated according to the politics of individual experience (supported by shared values).' It is possible and even fruitful to interpret these changes and shifts in terms of power when it includes the dimension of economy. At the end of his life the French philosopher Gilles Deleuze wrote about the changes in capitalism by use of the term 'societies of control', which refers to the new forms of power which advanced after the Second World War and are different

5 Anybody who has read scholarly discussion on fandom has encountered two opposite attitudes toward fans. Either fans are deemed as passive dupes who are blinded by consumer-capitalist ideology or they are seen as active textual poachers who are empowering themselves in everyday life despite the fact that some of the items which are important for being a fan are mass-produced commodities. When looking at the literature dealing with the relation between capitalism and spirituality, it is hard not to get the impression that there is something familiar in the ways in which the issue is discussed. 
from what Foucault described as disciplinary societies and its 'code of normalization' (Foucault 2004: 38). The main shift is from successive institutional moulds such as school, army, factory and hospital to more fluid but constantly changing modulation (Deleuze 1995: 169-82). By arguing about the changing tendency from the model of a mole's burrow to snake's coils not only in the system we live but also in the way we live with other people, Deleuze (1995: 179) proposes that 'businesses are replacing factories, school is being replaced by continuing education and exams by continuous assessment. This crisis of disciplinary institutions opens the possibility for the weakly institutionalised spirituality both to flourish, even though it does not make it necessary, and to be relocated for example in outlets, business, education and healthcare.

The institutional crisis is related to changing capitalism. Gilles Deleuze and Félix Guattari $(1983,1998)$ understand capitalism as a deterritorialising system which extracts its surplus from the differential flows of social relations. It is able to integrate the crisis of institutions and the new bloom of spiritualities that follow from incredulity towards the authority of institutions. From the perspective of the capitalist production of value, it was too costly to maintain and support the system of disciplinary societies. Therefore, the apparently free floating control is a suitable system for contemporary capitalism. It can turn the deterritorialisation of religion (and its reterritorialisation to spirituality) to cash value both at the level of consumer products and at the level of ideology. This, however, should not be understood as an all-encompassing framework, but as a potential approach in the analysis of spirituality in contemporary power struggles. It can also be supplemented with more recent theoretical developments.

Michael Hardt and Antonio Negri (2000) build their theory on this Deleuzean basis and argue that we are moving from a nation-based, monocultural and institution-driven colonial capitalism to the global or imperial capitalism where cultural/religious/spiritual differences are not excluded from but integrated into the capitalist production of value. Exclusion is not over in imperial capitalism, but its legitimisation and manner have changed, because the 'Empire' no longer creates (cultural, religious etc.) differences, but works with them.

Empire is, according to Hardt and Negri (2000: 198-200), 'a machine of universal integration', and 'complete cultural assimilation. . . is certainly not the priority of imperial strategy'. It accepts 'non-conflictual differences, the kind of differences we might set aside when necessary' and aims at 'the management and hierarchization of these differences in a general economy of command. This is what is called the triple imperative of imperial strategy 
with its three distinct moments: one inclusive (blindness to differences), another differential (exclusion of inflexible and unmanageable differences such as terrorism and extreme fundamentalism), and a third managerial (continuous modulation of identities). Thinking with the triple imperative is one possible model for understanding why differences are now supported and even celebrated more than during the era of colonial capitalism when modern institutional religions had their stable roles as part of the nation-states. Still it does not mean that spiritualities are simply products or supplements of global capitalism.

The problem with the detailed analyses of spirituality is the lack of a theory of capitalism. The logic of imperial capitalism, as outlined above, is such that it is able to accommodate itself to different religious and spiritual views. Whatever the problems are in applying this Deleuzean framework on the empirical study of spiritualities, the benefit of it would be the clarification of the possible connection between the logic of capitalism and the emergence of contemporary spirituality through historical change.

\section{Conclusion}

While it has become commonplace to study and accept the connection between national-colonial capitalism and the emergence of the category of religion (for example Chidester 1996, 2000; Fitzgerald 2000, 2007; McCutcheon 2003; Murphy 2007), we are still only beginning to think even the possibility of a connection between global imperial capitalism and the category of spirituality. To start thinking through these issues is not to argue that the time of the nation-states has totally passed. Instead, it is an opening to a better understanding of the complexity of the relations between local and global-and the role of the categories of religion and spirituality in those processes.

It may turn out that some empirical cases of spirituality are incompatible with this framework, but at least it is important to try to show exactly how some cases are pro-capitalist or anti-capitalist and in what way. Therefore, we need detailed ethnographic evidence, a sophisticated understanding of the complexity of contemporary capitalism and on the basis of these, an evaluation of what counts as an anti-capitalist dimension. So far the scholarship on this has cultivated some of these aspects, but has not combined them successfully.

My suggestion is that by taking the problem of capitalism seriously in the analysis of contemporary spirituality it is possible to understand social 
forms, roles and functions of spirituality better and make the scholarly study of it more interesting. I am not arguing that any kind of spirituality should be avoided if one wants to take part in the anti-capitalist struggle. ${ }^{6}$ I am simply saying that practices which are placed under the label of 'spirituality' have no intrinsic or necessary relation to capitalism or anti-capitalism. Therefore, as scholars we should be sensitive to the complex and most likely changing web of relations between contemporary spiritualities and capitalism, as well as spiritualities and anti-capitalism. I have suggested that some anti-capitalist critiques of spirituality make the connection between spirituality and capitalism all too simple and easy. At the same time, some writers who see spirituality as progressive, have almost omitted the problematisation of complexities of capitalism. What is needed is a balancing of these critiques and celebrations of discourse on spirituality.

\section{References}

\section{Bowman, Paul}

2007 The Tao of Žižek. In: Paul Bowman \& Richard Stamp (eds), The Truth of Žižek; pp. 27-44. London: Continuum.

\section{Carrette, Jeremy R.}

2000 Foucault and Religion: Spiritual Corporality and Political Spirituality. London: Routledge.

2004 Postmodern Spirituality. In: Christopher Partridge (ed.), New Religions: A Guide. New Religious Movements, Sects and Alternative Spiritualities; pp. 362-4. New York: Oxford University Press.

\section{Carrette, Jeremy \& Richard King}

2005 Selling Spirituality: The Silent Takeover of Religion. London: Routledge.

Chidester, David

1996 Savage Systems: Colonialism and Comparative Religion in Southern Africa. Charlottesville: University Press of Virginia.

6 This view differs from Žižek (2008: 183), who follows Alain Badiou in claiming that it is 'better to do nothing than to engage in localised acts the ultimate function of which is to make the system run more smoothly'. Although it is easy to follow Žižek's and Badiou's line of thinking, it is difficult, and perhaps unnecessary, to hold that position when scholars are working in the midst of the users of spiritual outlets. Even Žižek says elsewhere that one should support anti-capitalist anti-globalisation movements, for example. However, he wants to remain at a distance, because he is sceptical of the idea that things are getting better if we simply continue to support these movements without further theorising (see Žižek's lecture 'The Euthanasia of Tolerant Reason' at http://www.youtube.com/watch?v= $\mathrm{M}_{3} \mathrm{LF}_{3} \mathrm{ZN} \_\mathrm{Cxk}$ ). 
2000 Colonialism. In: Willi Braun \& Russell T. McCutcheon (eds), Guide to the Study of Religion; pp. 423-37. London: Cassell.

\section{Chopra, Deepak}

1993 Ageless Body, Timeless Mind. Crown Books.

\section{Critchley, Simon}

2003 Why I Love Cultural Studies. In: Paul Bowman (ed.), Interrogating Cultural Studies: Theory, Politics and Practice; pp. 59-75. London: Pluto Press.

\section{Deleuze, Gilles}

1995 Negotiations 1972-1990. New York: Columbia University Press.

\section{Deleuze, Gilles \& Félix Guattari}

1983 Anti-Oedipus: Capitalism and Schizophrenia. Minneapolis: University of Minnesota Press.

1998 A Thousand Plateaus: Capitalism and Schizophrenia. Minneapolis: University of Minnesota Press.

\section{Dewey, John}

1960 A Common Faith. New Haven: Yale University Press.

Fitzgerald, Timothy

2000 The Ideology of Religious Studies. New York: Oxford University Press.

2007 Discourse on Civility and Barbarity: A Critical History of Religion and Related Categories. New York: Oxford University Press.

\section{Foucault, Michel}

2004 Society Must be Defended. Lectures at the Collège de France 1975-1976. London: Penguin.

Hardt, Michael \& Antonio Negri

2000 Empire. Cambridge: Harvard University Press.

\section{King, Richard}

1999 Orientalism and Religion: Postcolonial Theory, India and 'The Mystic East'. London: Routledge.

\section{Kotsko, Adam}

2008 Žižek and Theology. London: T\&T Clark.

\section{Lau, Kimberly J.}

2000 New Age Capitalism: Making Money East of Eden. Philadelphia: University of Pennsylvania Press.

\section{Lynch, Gordon}

2007 The New Spirituality: An Introduction to Progressive Belief in the Twenty-first Century. London: I. B. Tauris.

\section{McCutcheon, Russell T.}

2003 The Discipline of Religion: Structure, Meaning, Rhetoric. London: Routledge. Murphy, Tim

2007 Representing Religion: Essays in History, Theory and Crisis. London: Equinox.

Žižek, Slavoj

1999 The Ticklish Subject: The Absent Centre of Political Ontology. London: Verso. 
Teemu Taira

2000 The Fragile Absolute. Or, Why is the Christian Legacy Worth Fighting for? London: Verso.

2001 On Belief. London: Routledge.

2003 The Puppet and the Dwarf: The Perverse Core of Christianity. Cambridge: MIT Press.

2004 Iraq: The Borrowed Kettle. London: Verso.

2008 Violence: Six Sideways Reflections. London: Profile Books. 